\title{
Post-pandemic Scenario for University Startup Accelerators
}

\author{
http://doi.org/10.21272/fmir.5(2).52-57.2021
}

Dr Abraham (Abi) Moskovicz, ORCID: https://orcid.org/0000-0002-5008-4420

Researcher \& Lecturer, the School of Business Administration, the University of Haifa, Israel

\begin{abstract}
This essay focuses on the post-Covid19 environment of entrepreneurial ideas that have potentials of success and growth in the coming years, providing an insight into the prolific funding being made available for University startups, especially in their early stages of development. To achieve this objective, it seems crucial to define firstly many terms frequently used and to determinate the involved variables. Whoever is able to predict this new post-Covid reality and glimpse the later scenario, will be better prepared for the new times, which will be as changing and indefinite as in the past. It seems the right time to transform ideas into realities. Whether it is a student presenting his thesis or an entrepreneur landing his postponed projects, this new scenario more than tempting forces to undertake. Through an University startup accelerator, it is possible to anticipate your competitors, learning about new proposals, counting on the advice and mentoring of independent professional experts. Universities with a sufficiently strong entrepreneurial ecosystem can serve as an ideal launch pad for startups founded by its own students and researchers.
\end{abstract}

Keywords: Startups, University, Accelerators, Entrepreneurs, Success

JEL Classification: M13, L26 \& L32.

Cite as: Moskovicz, A. (2021). Post-pandemic Scenario for University Startup Accelerators. Financial Markets, Institutions and Risks, 5(2), 52-57. http://doi.org/10.21272/fmir.5(2).52-57.2021

Received: 19 April, 2021

Accepted: 22 May, 2021

Published: 25 June, 2021

Copyright: (C) 2021 by the author. Licensee Sumy State University, Ukraine. This article is an open access article distributed under the terms and conditions of the Creative Commons Attribution (CC BY) license (https://creativecommons.org/licenses/by/4.0/)

\section{Introduction}

Ideas is what any startup begins from, but only these with a practical application. A startup is a human organization intended to create a new product or service under conditions of extreme uncertainty.

Startups may be founded by one or several entrepreneurs. It is any business venture that's starting from scratch and trying to build something of value, acompany or project initiated by an entrepreneur to seek, effectively develop, and validate a scalable business model.

The term startup refers to a firm in the first stage of its operations, typically small in nature, new, and funded by either to founding entrepreneur or a group of investors who believe in the founder or company concept. Therefore, startups refer to the new businesses that intend to grow large beyond the solo founder, making them possible for being commercialized.

Some startups become unicorns, privately held startup companies valued at over USD \$1 billion.

These companies usually face high costs fromthe very beginning and limited revenues which is why they look for capital from a variety of sources.

Since it is possible to make a deal with the author of the idea, there is no need be the venture's creator to become a startup founder. Baranichev (2011) suggests to search for projects at university campus. 


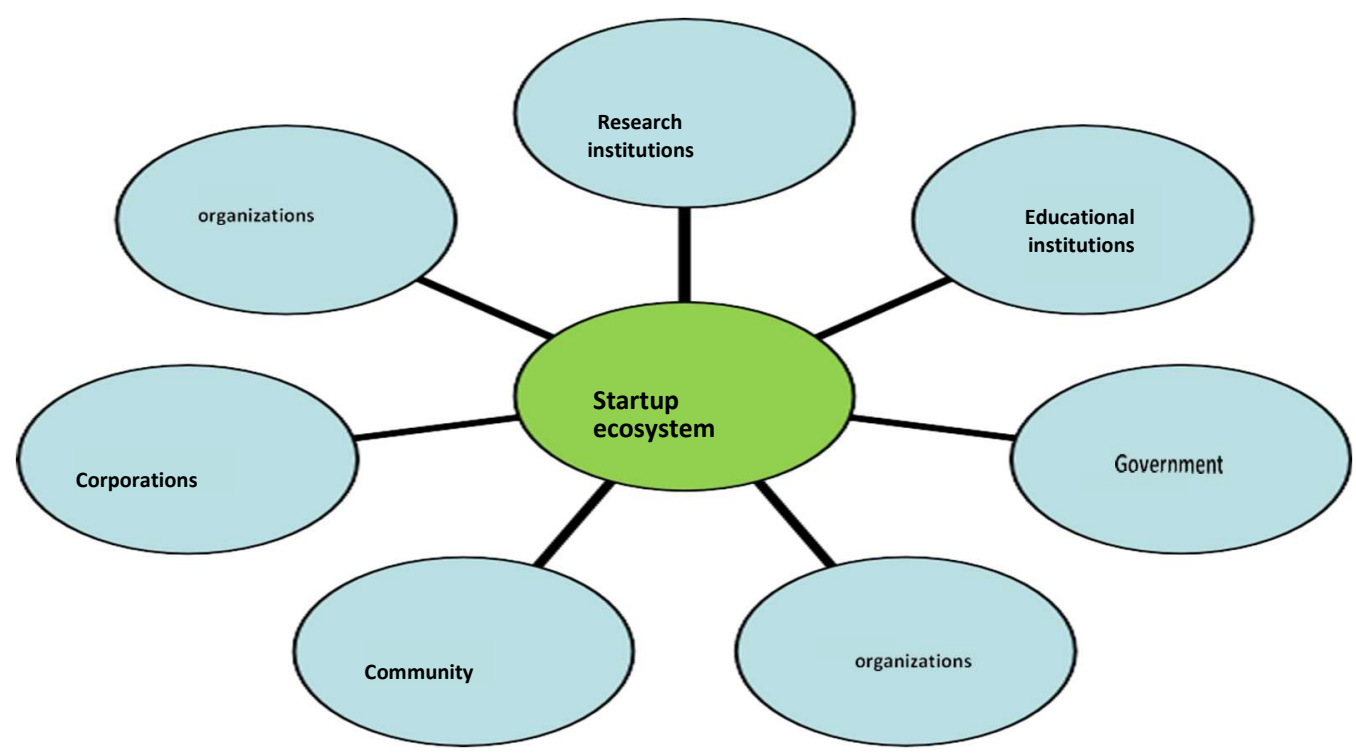

Figure 1. Startup Ecosystem. (Borocki \& Vekic 2017)

Source: Borocki, J \& Veric, A (2017) The Role of Institution in Supporting Startup Companies. XVII International Scientific Conference on Industrial Systems. Novi Sad, Serbia.

New startup companies often fail to survive within their very early stage of operation due to various

reasons such as founder's inexperience in managerial matters, the misunderstanding of the business landscape or the lack of financial support, among many other factors.

There are startup theories in three main areas:

Organization theories focusing on startups: Van de Ven (1984) studied entrepreneurial, organizational and ecological approaches. Organization theories are scarce on startup evolution.

Management theories focusing on startups, according to Hofstede (1999) they are more focused on those entities as individuals that coordinate their efforts toward some aim in common.

Entrepreneurship theories are focused mainly in the founder of the new company.

Nowadays there is a huge surge of interest in entrepreneurship, both inside and outside universities, as researchers and docents realize that to start their own firm may be more profitable than to spend an entire life at the campus.

Indeed, regarding to practical know-how about launching a startup, universities have a lot of work to do. They can offer attractive courses in entrepreneurship, infrastructure, mentoring, financial matters and funding, including startup grants. In fact, some universities are already a remarkable fame on this field as they link the students with companies that sponsor their research.

Therefore, Universities are platforms available to be properly used as springboards by new ventures.

Many stakeholders permanently exchange ideas with universities, allowing synergies to emerge.

Universities with a sufficiently strong entrepreneurial ecosystem can serve as an ideal launch pad for startups founded by its own students and researchers.

\section{Clusters, Incubators \& Accelerators}

Clusters are geographic concentrations of interconnected firms and institutions focused on a specific field, where a balance is reached between cooperation and competition, resulting in the higher productivity of the companies due their improved access to inputs, information, network, infrastructure, technology and institutions.

Incubation is as an unique as flexible combination of business development processes, infrastructure andpeople, intended to allow the growth of brand-new small companies since their early stages of development.

Incubation programs are usually sponsored by both private and public organizations, such as universities. 
According to Mian (2016), Business Incubators main goal is to help young businesses by providing them with necessary support, financial and technical services.

Wynarczyk \& Raine (2005) conclude that business incubators contribute in three ways: add value to the regional economy, improve outcomes for individual businesses and encourage the creation of new startups.

The International Business Innovation Association (InBIA) sustain that $87 \%$ of incubated firms are still in business after 4 years.

On the other hand, accelerators have a direct profit goal, that's the reason why many authors consider them as a one end of the venture capital spectrum.

As per Fehder \& Hochberg (2014), areas with established accelerators enjoy higher levels of entrepreneurial financing activity both within the accelerator and more widely.

Accelerators improve the growth of an existing company, while incubators host ideas to become a company, thus accelerators era centered on scaling a business while incubators are often more focusedon innovation.

Business Accelerators are a relatively new phenomenon, since the first was founded in 2005.

Miller \& Bound (2011) argue that "an Accelerator has five definitive features: (i) an application process that is opento all, yet highly competitive; (ii) provision of pre-seed investment, usually in exchange for equity; (iii) a focus on small teams and not individual founders; (iv) time-limited support comprising programmed events and intensive mentoring; and (v) cohorts or classes of startups, rather than individual companies".

Although this is a very comprehensive definition, it is not valid for every company in every place.

Accelerators have two distinguishing features: (i) shorter incubation period and (ii) selection and admission criteria.

Combining the definitions of accelerators as per Christianson (2009) and Miller \& Bound (2011) there is a remarkable presence of the following 8 characteristics: 1. Funding, 2. Small teams, not individual founders, 3 . Defined period 3-6 months, 4. Intensive coaching/education programme, 5. Networking, 6. An open highly competitive application process, 7. Demo Day at graduation and 8. Free of charge/subsidised office space (that excludes virtual accelerators).

Halt, Fesnak, Donch \& Stiles (2014) consider both incubators and accelerators as strategic mechanisms for universities to use their intellectual property assets.

University accelerators seems crucial as they mostly provide:

1. Training. Many accelerators include classes and one-on-one custom training provided by the accelerator staff or expert speakers in each field.

2. Startup Advice. Accelerator team and an extended network of ad-honorem expert mentors provide advice to the management teams of portfolio companies.

3. Coworking space. The accelerators that require startups to operate in a specific locationduring the class typically provide free office space as part of the supporting package.

4. Network. Potential investors, advisors, employees and experts in every matter.

5. Funding. Companies acquire the necessary resources to grow.

6. Reputation. The positive impact for a company as a result of being accepted to takepart of a high-level accelerator.

7. Monitoring. Business accelerators are responsible to oversee their investments on behalf of their investors.

As per Adomdza (2016) some university accelerators are managed by student-volunteers.

There are two main kinds of business accelerators:

Seed programs: last 2 to 4 months and focus on early stage startups, building up theirs business pillars before giving the opportunity to present their ideas to eventual investors. 
Second-stage programs: last up to 6 months, and focus on more mature firms, serving as a link to the full range of support and opportunities.

Table 1. Differences between Accelerators, Incubators and Business Angels

\begin{tabular}{|c|c|c|c|}
\hline & Accelerators & Incubators & Business Angels \\
\hline Duration & 3 months & $1-5$ years & Ongoing \\
\hline Cohorts & Yes & No & Investment \\
\hline Business model & Investment; non-profit & Rent; non-profit & Competitive; ongoing \\
\hline Selection frequency & Competitive; cyclical & Early;late & None \\
\hline Venture stage & Early & $\begin{array}{c}\text { On request, } \\
\text { HR/legal/accounting }\end{array}$ & Off-site \\
\hline Education & Seminars; workshops & On-site & On request, by investor \\
\hline Venture location & Usually on-site & $\begin{array}{c}\text { Minimal, and for a } \\
\text { remuneration }\end{array}$ \\
\hline Mentorship & Intense, by self and others & & \\
\hline
\end{tabular}

Source: Cohen, S. (2013).

University Accelerators help entrepreneurs navigate and survive the entrepreneurial "Valley of death", term used in the venture capital industry to refer a situation when a startup company closes its business before successfully generating its steady revenues.

Universities provide a better environment for students to found successful startups. As more links entrepreneurs have, and as higher their network of university alumni, increases their successful level. It is well known by now that entrepreneurs who are well-connected are more successful in their endeavors.

Raz \& Gloor (2007) argue that startup entrepreneurs are more successful if they communicate morewith their peers.

According to Ahuja (2000) and Burt (2004), it has already been shown that people connecting structural holes are more successful. On the other hand, we also speculate that people well embedded into the old-boys network of their university are more successful.

Murray (2004) suggests that academics who found biotech firms use their social capital to recruit collaborators through their own laboratory networks. Therefore, the better connected an entrepreneur is with peers of her or his alumni network compared to links with outside peers, the higher the probability of success.

An everlasting fight exists between universities, governments and non-profit organisations and the commercial intent of accelerators and their alumni, not to mention the conflict between universities that are ranked and rewarded by their success in retaining and awarding degrees to their students, andstartup founders who, if successful, should commit themselves unreservedly to their new ventures.

Carney $\left(\begin{array}{llll}2 & 0 & 1 & 3\end{array}\right)$ argues that $\mathrm{t} h \mathrm{~h}$ universities are punished by the immediate consequences of that success. In fact, successful university accelerators involuntarily encourage entrepreneurs to pursue off-campus their new ventures.

\section{Conclusions \& Recommendations}

Covid-19 crisis has caused drastic changes in uses, customs and practices, which simply add to the accelerated obsolescence that we have witnessed in recent decades, as inhabitants of this global village.

A commercial activity that previously took a lifetime to disappear, today it becomes demodé in a jiffy. Who would go out today on a bicycle to shout through the streets that sharpens knives or even invest in installing a videoclub?

These businesses may seem from prehistory, but surely several of you had the opportunity to meet them personally.

Once the governments lift the quarantines, we will not only find people wearing masks, keeping their distance and waving their elbows instead shaking hands, but also several broken businesses, includingsome stores that we believed to be eternal.

Airlines, restaurants, hotels, cinemas, artists and sports clubs are the most frequently mentioned victims,but not the most affected. Precisely the aforementioned, either through their access to credit, financing, state aid or injection of funds from their owners, will somehow float. 
It is the entrepreneurs who will feel the blow the most, since all doors are closed to them, at a time whenthey observe how the supposedly successful effort of decades disappears after a few weeks of crisis.

Given this, they will conclude that it is better to be employed in the public administration or look for some salaried job.

Therefore, the greatest harm of this crisis is that it can severely undermine the urge to risk undertaking. This might be lethal for future development since it is precisely these daring dreamers who are driving the changes, with their creativity and imagination.

Thus, it is possible to assert that in the coming years we will see a stagnation in the development of new projects, except for those that are directly related to the coronavirus cure.

Even projects already runningwill have to be put on hold in order to be reevaluated in the post-Covid scenario, and several of them will might be finally aborted.

Banks will require higher guarantees, the amounts available will be less and the most ambitious projectswill be relegated in favor of the safest, although with less profitability.

The Marshall Plan, so often used as an example, has the virtue of having provided fishing rods to the devastated nations, not the fish already served.

In the same way, Universities provide tools, no gifts.

In short, when we get out of this gradual quarantine, we will find a world that, except for the obvious in sight (masks and distances), has also changed its customs, once again modifying people's preferences and their consumption habits.

It is possible to assert that in the coming months we will see a stagnation in the development of new projects, except for those that are directly related to the coronavirus cure. Even the ventures that were already being implemented will have to be paused to be evaluated again in the post-Covid scenario, and several of them will eventually be scrapped.

The question is to adapt or to die, as mercy is not among market rules.

There is also no possibility of appeal.

From a positive perspective, crises cause a removal of society foundations,

and sometimes this is a driving force for new inventions and better laws.

Whoever is able to read this new reality and glimpse the later scenario, will be better prepared for the new times, which will be changing and indefinite as always.

University startup accelerators help to manage the several risks involved.

It seems the right time to transform ideas into realities.

Whether it is a student presenting his thesis or an entrepreneur landing his projects so often postponed, this new scenario more than tempting forces to undertake.

Academia attracts talented entrepreneurs as well interested external stakeholders.

When their energy is unified toward a common goal, this environment provides to the startups much stronger resources than the private sector alone can do.

I strongly encourage the expansion and improvement of University accelerators, where due its idealStartup Ecosystem, makes possible to anticipate competitors, to learn about new proposals, and counting on the advice and mentoring of professional experts.

\section{References}

1. Behar, R. (2016) Inside Israel's secret startup Machine. Forbes, May 31. [Link]

2. Cohen, S. (2013) What do Accelerators do: Insights from incubators and angels. MIT Press. Innovations: Technology, Governance, Globalization, 8, 3-4 (Summer-Fall 2013): 19-25. [Link] 
3. Eckhardt, J. (2015) Should I participate in a Business Accelerator. Entrepreneur \&Innovation Exchange.

4. Fowle, M. (2017) Critical success factors for business accelerators: A theoretical context. Warwick Business School. Project: HEFCE Catalyst PIPE Project. [Link]

5. Jensen, R. (2015) University Startups and Entrepreneurship: New Data, new result. University of Notre Dame. [Link]

6. Kanbach, D. \& Stubner, S. (2016) Corporate accelerators startupengagement: The what, the why and the how. [CrossRef]

7. Kotys-Schwartz, D. (2019) Assessment of a cross-disciplinary University startup accelerator. [Google Scholar]

8. Salamzadeh, A. \& Kawamorita, K (2015) Startup Companies: Life Cycle and challenges. EEE Conferences. [CrossRef]

9. Showalter, D. \& Jensen R (2019). University Startup intensity and Faculty quality. Economic Enquiry. [Google Scholar]

10. Stagars, M. (2014). University Startups and Spin-offs: Guide for Entrepreneurs in Academia. Apress. [Google Scholar]

11. Stagars, M. (2015). Why are University accelerators not taking off ResearchGate. [Link]

12. Swamidass, P. (2011). The challenge facing University Startups in USA. Retrieved from: [Google Scholar]

13. Torun, M. (2016). Business accelerators and their differences from incubators. [Google Scholar] 